\title{
MANAGEMENT OF INTEGRATED MADRASAH DINIYAH CURRICULUM DEVELOPMENT AT SD KHAZANAH ILMU SIDOARJO
}

\author{
Mohamad Rojii ${ }^{1}$, Istikomah ${ }^{2}$, Choirul Mahfud ${ }^{3}$, Moh. Saifulloh ${ }^{4}$, Muhammad Zuhair ${ }^{5}$ \\ Fakultas Agama Islam, Universitas Muhammadiyah Sidoarjo, dan Institut Teknologi Sepuluh \\ Nopember (ITS) Surabaya, Indonesia. \\ Email:mohamadrojii1993@gmail.com¹, istikomah@umsida.ac.id², choirul.mahfud@its.ac.id², \\ saiful@mku.its.ac.id ${ }^{4}$, muhammadzuhair01@gmail.com ${ }^{5}$
}

DOI: https://doi.org/10.29313/tjpi.v9i1.6286

Submitted: June 16th, 2020. Approved: June 29th, 2020. Published: June 29th, 2020

\begin{abstract}
Madrasab Diniyah emerged as a place for religious education for people who wanted a portion of their children's religious education. If this Diniyah Madrasah can be run according to its function and managed with good management, then the Diniyah Madrasah can be one solution to the problems of Religious Education in Indonesia. This study aims to reveal how the management of Madrasah Diniyah curriculum development is integrated into primary education institutions. This research includes qualitative research; data collection is done by collecting documents, conducting interviews, and observing at the research site. This study's data were analyzed using analytical techniques, including reduction, presentation of data, and concluding. The results of this study stated that the management of the integrated Madrasah Diniyah curriculum at SD Khazanah Sciences was carried out with a process including planning, organizing, implementing, monitoring, and evaluating the founders as initiators of curriculum development ideas at the institution. After that, a curriculum development team was formed with specific tasks according to their respective responsibilities to start the curriculum development process based on philosophical, psychological, sociological, and juridical foundations.
\end{abstract}

Keywords: Management Curriculum Development, Integrated Madrasah Diniyah, Basic Education Institutions.

\begin{abstract}
Abstrak
Madrasah Diniyah muncul sebagai wadah pendidikan Agama bagi masyarakat yang menginginkan porsi pendidikan Agama yang lebih banyak bagi anak-anak mereka. Jika Madrasab Diniyah ini dapat dijalankan sesuai dengan fungsiny a dan dikelola dengan manajemen yang baik, maka Madrasah Diniyah dapat menjadi salah satu solusi bagi permasalahan Pendidikan Agama di Indonesia. Penelitian ini bertujuan untuk mengungkap bagaimana bentuk. manajemen pengembangan kurikulum Madrasah Diniyah yang terintegrasi pada lembaga pendidikan dasar. Penelitian ini termasuk jenis penelitian kualitatif, pengumpulan data dilakukan dengan cara mengumpulkan dokumen-dokumen, melakukan wawancara, dan juga melakukan observasi di tempat penelitian. Adapun data pada penelitian ini dianalisis dengan menggunakan teknik analisis yang meliputi reduksi, penyajian data, dan penarikan kesimpulan. Hasil penelitian ini menyatakan bahwa manajemen pengembangan kurikulum Madrasah Diniyah terintegrasi di SD Khazanah Ilmu dilaksanakan dengan proses meliputi perencanaan, pengorganisasian, pelaksanaan, pengawasan, dan evaluasi para pendiri sebagai inisiator ide pengembangan kurikulum di lembaga tersebut. Setelah itu, dibentuklah tim pengembang kurikulum dengan tugas-tugas khusus sesuai tanggung jawab masing-masing untuk memulai proses pengembangan kurikulum dengan berlandaskan pada landasan filosofis, psikologis, sosiologis, dan yuridis.
\end{abstract}

Kata Kunci: Manajemen Pengembangan Kurikulum, Madrasah Diniyab Terintegrasi, Lembaga Pendidikan Dasar. 


\section{INTRODUCTION}

Every country would expect the best life for its people. Starting from a peaceful life, safe to be economically stable. Many people want to realize these hopes of the best in life. Several paths are taken, one of which is through education. In Indonesia, the government has set the goals of national education. Of course, all parties are obliged to succeed. In this era of globalization, people are faced with a problem that affects almost all levels of society-starting from the Corona pandemic problem to other global problems. The point is that this problem arises from human civilization that is wrong in its development on the one hand.

On the other hand, these developments also further alienate society from ideal educational goals. Specifically, in Indonesia, the government tries to provide policy solutions that have been determined by the government, especially at the level of faith and piety. The global problem is also what encourages futurologists to state that in the 21st century, human beings are increasingly yearning for religious life. In this state, humans are experiencing turbulent inner conflicts. This problem results from the gap between science and technology development, which is inversely proportional to human faith and piety. This problem is what ultimately affects the psychological condition of humans. In the end, humans will struggle to regain the inner peace they hoped for Jalaluddin, 2012).

In Islam, good attitudes, which are the goals of education mentioned above, are summarized in two words: Akhlakul Karimah, which means good character. The most important mission of the Prophet Muhammad was to improve human morals. Following the words of the Prophet Muhammad SAW, which means:
"Verily I (Muhammad) was sent to perfect Morals" (Al-Jazairi, 2009). In Islam, good morals are a practice that will burden human scales on the Day of Judgment. It is recorded in the hadith of the Prophet Sallallahu Alaihi Wassallam. He said: "Nothing that is on the scale weighs more than moral goodness" (Al-Jazairi, 2009).

The best way for Muslims in Indonesia to be able to return to the national education goals that have been dreamed of for a long time is by providing sufficient understanding of religion to the nation's sons and daughters so that they will be ready to carry out the country's duties in the life to come. The goals of national education will be achieved. The problems that are troubling all of us in the current era of globalization can be resolved. The description above about the importance of Islamic religious education in today's era is reinforced by Shaykh Burhan-Al-Islam Az-Zarnuji, summarized in his phenomenal book, the book Ta'lim Muta'allim Thariiqut Ta'allumi. He quoted the beautiful advice of a prominent scholar of his time, Muhammad bin AlHasan Bin Abdullah, who advised people to study the science of Religion. According to him, religion is the most superior science, knowledge as a guide to goodness and piety, the straightest knowledge and knowledge that leads to the straightest path, namely the path of guidance from Allah. Religion is like a strong fortress that fortifies humans from all kinds of problems (Burhan Al- Islam Al-Zarnuji, 2004).

If you look at the statement above, Islamic religious education is the most critical concern in education to perfectly achieve national education goals. However, the fact is that there are indeed many criticisms of the implementation of Islamic religious education in Indonesia. These criticisms relate to the orientation of religious education learning in schools, which is more of a mere cognitive aspect 
and cannot convert it into students' values. Criticism is also aimed at the approaches. Methods and techniques of teaching Islamic education carried out by the teachers it has not been able to create learning that has succeeded in making students ready for religious practice according to the knowledge they have acquired so that Islamic religious education is considered unable to contribute, which means the achievement of national education goals (Minarti, 2013).

From the criticisms of the implementation of Islamic religious education in Indonesia as described above, other possible solutions can be taken to help the task of more solutive Islamic education (Mahfud, 2016; Mahfud, 2019; Mahfud, 2020; Krisdiyanto, 2019). The author's solution is maximizing the role of Madrasah Diniyah, which has given many colors during society. Madrasah Diniyah, as we know, is a non-formal institution. The community organizes it. Interestingly, its purpose is also for society. The main objective of holding Madrasah Diniyah itself is as stated in the guidebook for administering Madrasah Diniyah. It states that Madrasah Diniyah must be the first pillar and foundation in building the nation to prepare future generations who are well-informed about religion, have insight, have adequate life skills, and have noble character.

If appropriately organized and with good management, Madrasah Diniyah can be an appropriate alternative to complement the gaps and problems of Islamic religious education held at formal educational institutions, as described in the Madrasah Diniyah curriculum standard manual. The content of the material taught at Madrasah Diniyah, in the book, it is said that in the future, the children will get a much larger portion of Islamic education lessons, and the material will be divided into five main subjects, namely: Al-Qur'an, Al-Hadith, Fiqh, Tauhid, Akhlaq, and Islamic History (Ministry of Religion, 2017).

In Islam, arranging a case to make it better is part of the teachings of Religion. Managing a case or managing something to make it better and more useful are Islamic teachings in the contents of the al-Qur'an Surah As-Sajadah: 5). However, it is regrettable when the facts on the ground are found that the implementation of Madrasah Diniyah during society is still far from satisfactory. With management far from being a professional word, learning methods tend to maintain traditionalism and have not received many touches with modern methods. Teachers' conditions are also considered to be of great concern because of their lack of attention to their welfare. In essence, many Madrasah Diniyah teachers have not received guaranteed wages from their hard work in teaching. Except for certain Madrasah Diniyah, which have implemented a monthly withdrawal policy for santri and are supported by the disbursement of incentive funds for Madrasah Diniyah, teachers from the ministry of education are insignificant and only affect minority Madrasas Diniyah in Indonesia. From students, some problems never get a solution. Where there are very few students who want to study at Madrasah Diniyah, which is held in the afternoon after learning hours at formal schools are over. Besides being considered not very important by their parents, learning in the afternoon after the formal learning time in schools also feels tiring.

In this article, the discussion's primary focus is directed at efforts to telescope the implementation of Madrasah Diniyah as a treasure of knowledge in Sidoarjo. There are many academic arguments that the point is that Madrasah Diniyah can very nicely integrate Madrasah Diniyah learning with the 
implementation of learning at elementary education institutions, namely elementary schools of knowledge. From the data that the authors obtained, the authors obtained information that the integration of Madrasah Diniyah in SD Khazanah Ilmu has resulted in a new curriculum structure that is different from primary schools in general. In the curriculum structure, the subject hours for Islamic Religion are far more than in other schools. The new curriculum structure that has been generated provides the portion of hours for Islamic Education subjects to reach $27.3 \%$. It is undoubtedly an exciting topic to be investigated further. The author also focuses on this research on curriculum development management at Madrasah Diniyah to be integrated with elementary education institutions (SD Khazanah Ilmu) very well, and can produce a new curriculum framework that highly emphasizes Islamic Religious Education which has Indonesian and Islamic nuances.

\section{RESEARCH METHODOLOGY}

This research can be said as qualitative research with a case study approach where the research data is generated from a search in a field study with the research location in SD Khazanah Ilmu Sidoarjo as it is known that case studies are one of the approaches among several approaches in qualitative research (Kisbiyanto, 2014). From several existing models of qualitative research approaches, a case study model was used for this research.

This research is also a descriptive research type, a type of research that attempts to show a picture or describe a situation as clearly as possible. For research subjects as sources of information, the researchers divided them into two categories, namely: the primary sources came from the head of the foundation, the principal, the principal of Madrasah diniyah, and ustadz-usdazah at SD Khazanah Ilmu. Supporting sources come from the ministry of religious affairs, administrative staff at Madrasah diniyah, students, and employees. Importantly, for research instruments as a means of extracting data, researchers used interview, observation, documentation techniques, so in searching for data, apart from conducting interviews with teachers and school principals, we also made observations to students at SD Khazanah Ilmu Sidoarjo, and read documents. at SD Khazanah Ilmu Sidoarjo which we need to perfect this research. The data that has been obtained is then analyzed using Miles and Huberman's theory of analysis.

\section{RESULTS AND DISCUSSION}

\section{The Theory of Curriculum Development Management}

In a general sense, management comes from the English "Administration," which is given the meaning "the Management of executive affairs," which means managing executive affairs. Management also has its origin from the word to manage. Standard processes and levels generally carry out management according to the function of management. In addition to the above meanings, several definitions of management have been conveyed by many experts. Hasibuan said that management is a science and art discipline that tries to regulate using all available resources to effectively and efficiently achieve a goal (Mustari, 2013).

Simply, the authors understand that management is a systematically structured process that includes planning, coordinating, controlling, and controlling by utilizing all kinds of resources that allow the benefits to be taken-based on the previously formulated objectives 
effectively and efficiently, it can be more clearly explained that management is a social process involving several people. Management is carried out by utilizing various resources that include human, material, cost, information, etc. Management is carried out with the principle of being effective and efficient in labor, cost, time, etc. Management must also be based on specific goals that have been formulated and agreed upon previously (Hamalik, 2007).

The main functions of management in education itself can be adequately divided into four main functions which can be explained as follows: First, planning, which is divided into two main functions, namely, 1) Endeavoring the implementation of a process of compiling a series of activities to be carried out by utilizing various existing resources following the goals to be achieved. 2) Maximizing the limitations of existing resources to achieve the goals that have been set. Second, implementation is a concrete action in order to realize the existing plan. Third, supervision is an activity by trying to make systematic and continuous observations by recording, providing explanations, coaching, and confirming everything deemed inappropriate and trying to find a solution. Fourth, coaching is a series of efforts to professionally control all organization elements to properly and efficiently carry out their functions and carry out all their responsibilities (Hamalik, 2007).

Management functions that have been mentioned above may be simplified and summarized as the management processes and functions mentioned by Oemar Hamalik in his book Curriculum Development Management. Hamalik said that the functions of management include planning, organizing, implementing, monitoring, and evaluating. Alternatively, sometimes abbreviated in English as
POAC (Planning, Organizing, Actuating, and Controlling) While the meaning of curriculum development is a process to answer needs that arise and future (Ibrahim, 2016). In another sense, it is stated that curriculum development is the entire process to improve the existing curriculum. This process also involves taking national goals and educational directions and targets into a plan related to the goals and objectives to be realized. This process is related to the planning of teaching and learning activities.

According to Sukmadinata, the meaning of curriculum development is rearranging and perfecting the existing curriculum. Sukmadinata also explained that curriculum development must start from preparing curriculum tools, including basic, structure, learning programs, and application guidelines. Meanwhile, according to Arif Furchan, curriculum development attempts to create and produce a curriculum in each academic unit by linking existing components. This activity is carried out through curriculum preparation, curriculum implementation, curriculum assessment, and curriculum refinement (Asrohah and Alamsyah, 2013). From the various meanings above, it can be concluded that the meaning of curriculum development is a process or a series of activities which include curriculum preparation, curriculum implementation, assessment to curriculum improvement. Curriculum development management studies is a branch of educational disciplines that have a comprehensive scope. This study seeks to study the curriculum as a whole by going through a functionally appropriate process rather than curriculum management. Of course, education experts have recognized this, including in the field of curriculum development.

The core and most essential activities in curriculum development 
management studies cover various fields: planning, development, implementation, evaluation, and curriculum improvement. Management planning and curriculum development are carried out based on the data obtained regarding the problems that have been faced and the urgency of planning or curriculum development. Management of curriculum implementation is carried out when the previously planned curriculum is mutually agreed upon to be ready for operation. Management of curriculum improvement is carried out if the curriculum that has been implemented faces obstacles or problems that require improvement and development as an effort to improve the quality of education.

Curriculum evaluation management is carried out based on the premise that all curriculum operational processes require an accurate data management container as a consideration in carrying out its work steps. From the explanation above, it can be seen that curriculum development management has a cycle that continues to rotate and is continuous (Asrohah and Alamsyah, 2013).

\section{Brief History of Madrasah Diniyah in Indonesia}

The forerunner to the birth of madrasah diniyah in Indonesia cannot be separated from Islamic religious education in the past, held in mosques and langgar. Over time, around 1909, the first madrasah appeared that used the classical system or used classrooms for learning. This madrasah was first established in Padang (Minangkabau) by Shaykh Abdullah Ahmad, named the Adabiyah school. In the following years, the adabiyah school had changed its name to H.I.S. Adabiyah, Sekolah Rakyat, S.M.P., so that in the end, changed its name to madras School (religious school). This religious school has been running for a while, focusing on studying the books of the scholars. However, in 1913, this religious school was forced to close due to lack of space. In 1918, Mahmud Yunus managed to re-establish a similar school called Al-jami'ah Islamiyah which still exists today under Bidayatul Islamiyah. From the religious school that was first established in Minangkabau, in 1915, a figure named Zainuddin Labai Alyunusi succeeded in initiating a center for Islamic religious education that he named Madrasah Diniyah. From here, Madrasah Diniyah finally spread to various areas in Minangkabau with very rapid development. The emergence of a special madrasah diniyah for women, pioneered by Rangkayo Rahman Al-Yunusiyah. Furthermore, in 1922, an association of madrasah diniyah students was formed, named P.M.D.S, or the association of diniyah school students (Nizah, 2016).

Other sources state that the roots of the emergence of madrasah diniyah in Indonesia are not the original legacy of educational institutions in Indonesia. It could be true that the beginning of the emergence of this madrasah diniyah was from the initial activities, namely learning Al-Quran, which was carried out in mosques, langgar, and intellectual houses of worship. However, this legacy is not purely from the Indonesian people. It is the legacy of the wealth of civilization in the Islamic world, which originated from the center of Islam, namely in the Middle East, which began to develop since the 1011 century $\mathrm{AD}$, the origin of the growth of this madrasah diniyah because it was pioneered by three forms of Islamic education institutions, namely the mosque stage, mosque, and madrasa institutions. This opinion is also strengthened by the condition of Islamic education in the Middle East around the 20th century, which has indeed moved towards a modern direction, namely by teaching 
religious knowledge and general sciences while they named madrasas places of study. Whereas in Indonesia itself, in the years around that century, the term madrasah was not familiar (Badrudin, 2017).

According to Karel A. Steenbrink, a professor from the Netherlands who is an expert on the history of Islam in Indonesia, in the early 20th century, Islamic education was usually carried out at several levels. The first is the recitation of the Al-Quran. At this level, the students are only focused on learning how to read and write the Alquran correctly and adequately. Apart from that, students are also required to start memorizing the $\mathrm{Al}$ Qur'an letters, especially the letters used for the five daily prayers. The second level, to improve the procedures for worshiping correctly, such as prayer, wudlu, fasting, etc. At this level, the students are also taught do'a-do' to practice in their daily lives. Learning at this level is carried out in the mosque/ surau and is sometimes held in one of the houses of people considered to have positions at that time.

Meanwhile, the third level is studying the ulama's books. At this stage it is different from the previous level. At this level, the students learn by being gathered in a place called a dormitory. The subjects taught have also begun to expand, including Arabic, fiqh, tauhid, ushuluddin, nahwu, shorof, tasawuf, hisab, astronomy, and so on. Students learn individually and have started to carry out learning in groups with other students (Ismail, 2018).

The modernization of Islamic education in Indonesia was visible around the end of the 19th century to the 21st century. During that time, many religious figures in Indonesia started to initiate Islamic educational institutions, both in Islamic boarding schools and madrasas. These institutions' establishment almost evenly covers various regions in the archipelago, especially in Java and
Sumatra. Two main factors at least influenced the modernization of the education system in Indonesia at that time. First, the Indonesian Muslim community began to doubt the traditional Islamic education system to compete in the future and produce quality graduates. Second, the Muslim community also began to worry about the Dutch-owned schools that were growing and continued to erode Islamic values in education and emphasized secularism's teachings. These two things ultimately demand the formulation of a new form of Islamic educational institutions that is more modern but still thick with Islamic values.

Furthermore, one of them is the emergence of the neglected Islamic school, which is now known as madrasah diniyah. However, Madrasah Diniyah patented was introduced only around 1964 after the Minister of Religion's decision number 13 was issued regarding the Madrasah Diniyah curriculum. After the issuance of this decision, Madrasah Diniyah emphasized its position amid madrasas and pesantren that had previously received recognition from the government. However, madrasah diniyah still holds the status of a non-formal institution in the government. In 2014, Minister of Religion Regulation No.13 was re-issued, which further strengthened Madrasah Diniyah as a formal government institution that was equivalent to madrasah and pesantren. This rule was born after the passing of law No.20 of 2003 concerning the national education system. Furthermore, law no.55 of 2007 regarding religious education and religious education was also issued (Ismail, 2018).

The point is that the roots of the emergence of madrasah diniyah can be said from teaching and learning activities held in mosques and houses of respected religious figures. After a time, this traditional system began to be developed and improved in line with modernizing 
Islamic education in Indonesia, until finally, there were institutions called Madrasahs, Pesantren, and Madrasah Diniyah. However, the formal ratification of Madrasah Diniyah was only realized after the issuance of the law. Number 13 of 2014 concerning Islamic religious education, which also decides the curriculum framework for madrasah diniyah and makes it part of a formal institution.

\section{The legal basis for administering Madrasah Diniyah in Indonesia}

In its history, the existence of madrasah diniyah has contributed significantly to society from the start. However, the development of madrasah diniyah to become an institution that can be equal to schools, pesantren, and madrasah or even to complement these institutions has experienced many obstacles, among these obstacles are: 1) the lack of interest of students studying at madrasah diniyah. The working hours of Madrasah Diniyah are only in the afternoon and at night, making it difficult for children to join to study at Madrasah Diniyah.

Besides, full-day school programs are also popular and influence parents who prefer to use their children's spare time to study materials at school either independently or to join tutoring institutions. 2) The lack of students' ability to read and write Arabic letters, Madrasah diniyah teaching materials that use classical Arabic books are indeed challenges and difficulties for students studying at Madrasah diniyah. It makes the students' understanding of the material less optimal. 3) Less innovative and varied learning methods are also one reason Madrasah diniyah are challenging to develop and compete with other educational institutions (Nurzaman, 2018).
During the 1989 era, religious education received intense attention from the government. Several sessions were conducted by the MPR (People's Consultative Assembly). The MPR drafted guidelines from 1973 to 1983, in which there was an emphasis that Islamic religious education was a compulsory subject for public schools at all levels. However, the new policy only accommodates taking religious education to be placed in schools and madrasas. Not at Madrasah Diniyah, in other words, religious education at Madrasah Diniyah has not received the government's attention correctly (Badrudin, 2017). With so many obstacles faced, Madrasah Diniyah continues to exist and develop. Making many parties involved in Madrasah Diniyah try very hard to keep Madrasah Diniyah in order to exist in society, one of which they are fighting for is recognition from the government of the existence of this Madrasah Diniyah. Finally, thanks to their struggle, which is dominated by scholars, teachers, and community assistance who still have an awareness of the importance of Madrasah Diniyah as a home for Islamic learning for their future generations. With all the might and effort they put in.

In the end, it gave encouraging results, with the issuance of law number 2 of 1989. The law contains the coverage of national education, which includes: Formal and informal education, and Madrasah Diniyah included in the category of informal educational institutions. Then the affirmation of the position of Madrasah Diniyah was also reinforced by government regulation No.73 of 1991 regarding the government's commitment to continue to provide religious education institutions for students who lack religious education in their places of study, either schools or madrasas, one of the institutions provided by the government is an institution. 
Informal madrasah diniyah (Nurzaman, 2018). However, in response to the policy, there were two opposing groups. Support groups argue that the decision is an aspirational policy following the public's desire to build human resource capacity with faith characteristics.

Conversely, the opposing group argued that the policy could interfere with the proposed school calendar (Badrudin, 2017). Inputs and criticisms have always decorated government decisions, including, in this case, government regulation regarding the recognition of the position of Madrasah diniyah. However, this did not affect the government much in making different policies regarding madrasah diniyah.

Evidence of the government's seriousness in paying attention to the existence of Madrasah Diniyah is evidenced by the passage of law No. 20 of 2003 concerning the national education system, which confirms the existence of madrasah diniyah. This law states that madrasah diniyah is given the same opportunity to grow and develop together with other educational institutions. The government also provides fair and proportional treatment to all educational institutions under its auspices. This law is also supported by several ministerial regulations issued afterward. These regulations are PP. 55 of 2007 Part I Article 1, paragraph 2, which contains religious education for Muslims consisting of Islamic boarding schools and madrasah diniyah, is given in various channels and education levels.

The government provides opportunities for religious education institutions to provide formal, nonformal, and informal education. "PP No. 55 of 2007", Part III Article 9, paragraph 2. It reads: The knowledge taught at Madrasah Diniyah comes from the teachings of Religion. "PP No. 55 of 2007 Part III of Article 10, paragraph 1". It reads: Islamic Religious Education can be given in the form of Madrasah Diniyah and Pesantren as stated in "PP No. 55 of 2007, Article 14, paragraph 1". Madrasah diniyah are regulated formally, nonformally, and informally, "PP no. 55 of 2007, Article, 14 paragraph 2". Madrasah Diniyah has become an official educational institution with roots in Islamic teachings ranging from early childhood education, basic education, secondary education, and higher education. "PP No. 55 of 2007, Section 15". The Madrasah Diniyah level, equivalent to MI / SD, consists of 6 (six) years of study programs and is followed by the next level, namely secondary education, equivalent to MTs / SMP, consisting of three (3) levels. Madrasah Diniyah secondary education level, equivalent to MA / SMA, consists of (3) three levels.

As a non-formal institution, Madrasah Diniyah is managed in various forms: religious lectures, classical books, Al-Qur'an education, Diniyah Takmiliyah, and other similar forms "PP No.55 of 2007, Article 21, paragraph 1". Regarding the form of education, non-formal education can be carried out in the form of schools or academic units. "PP No. 55 of 2007, Article 21, paragraph 2 ". Madrasah Diniyah that develop into educational units must obtain permission from the Ministry of Religion in the district/city after they meet the requirements for establishing an educational unit. At the regulation of 55 of 2007, Article 21, paragraph 3 stated that Madrasah Diniyah aims to provide Islamic education obtained at SD / MI, SMP / MTs, SMA / MA, SMK / MAK, or higher education to increase the faith piety of students to Allah. And, "PP No. 55 of 2007, Article 25, paragraph 1". Regarding the institutional hierarchy or educational level, Madrasah Diniyah can be implemented at a hierarchical or non- 
hierarchical level. " 55 of 2007, Article 25, paragraph 2". The place where Madrasah Diniyah is conducted can be implemented in a mosque or in any other place that meets the requirements. "PP No. 55 of 2007, Article 25, paragraph 3". Madrasah Diniyah, in the form of Diniyah Takmiliyah lies in the authority of the organizer. "PP No. 55 of 2007, Article 25, paragraph 4". In terms of implementation, Diniyah Takmiliyah can be done in Indonesia together with SD / MI, SMP / MTs, SMA / MA, SMK / MAK or higher education (Badrudin, 2017).

The most recent government regulation that forms the legal basis for implementing madrasah diniyah is the minister of religion of the Republic of Indonesia No. 13 of 2014. The regulation discloses of Islamic religious education. It is explained that madrasah diniyah is a part of non-formal religious education. It is to be precise in chapter III of Article 45 paragraph (1) which states that non-formal diniyah education is held in the community in the form of madrasah diniyah takmiliyah institutions (Djahid, 2016).

After examining the long journey, madrasah diniyah in obtaining recognition and legal basis from the government. Finally, we know that madrasah diniyah are indeed very important and become educational institutions expected by the Muslim community to provide a balanced portion of education for their children. In essence, religious education, which has not been fully fulfilled by traditional schools until now, has finally obtained a legal institution recognized by the state to provide improvements in providing Islamic religious education to the Muslim generation during society.

\section{Islamic Religious Education Curriculum in Elementary Schools}

When discussing curriculum, it can be said that the curriculum is an essential part and will never be separated from education. There are education experts who state that to foster and guide students in all their potential, which includes physical, intellectual, moral, and spiritual potential, the curriculum is stated as a design of an educational program that has objectives in it, namely: content, materials, methods, and evaluation of student learning outcomes. The education curriculum has a significant role as a building built to transfer the noble cultural values of the past, which are still feasible to be applied today as a counterweight to the development of the modern world, which lacks noble values to be used as a foothold (Mundiri \& Hasanah, 2018 ). In this discussion, the curriculum that will be studied is the Islamic religious education curriculum, which always gets quite intense attention both by observers and actors in education itself.

Islamic religious education is a mandatory requirement that must exist in society. The obligation to provide Islamic religious education at every level of education has been regulated in the National Education System Law No. 13 of 2003 , article 13, in which it is written that "every student has the right to receive religious education lessons under his / her religion and is taught by educators of the same faith as him" (Subakti, 2012). Islamic education's main objective is to develop human beings into faithful, pious, and have good character / noble character. In Indonesia, concerning Islamic religious education, it is different from other countries, the department is the department of religion. Besides that, Indonesia also has a particular ministry in charge of taking care of everything. The religious sector in Indonesia, namely the 
ministry of religion of the Republic of Indonesia.

The presence of a particular department in charge of the religious sector also impacts Indonesia's Islamic education characteristics, which is different from other countries. Islamic education in Indonesia has two curricula, which are covered by two different departments. The first is the Islamic religious education curriculum under the auspices of the department of religion, which includes several content subjects, these subjects are Al-Qur'an and Hadith, History Islamic culture, Fiqh, Aqidah Akhlak, and Arabic. All of these subjects are taught with different studies, unique curricula. From the religious department, this can be applied by schools that are under the auspices of the religious department, namely Pondok Pesantren, Madrasah, and Madrasah Diniyah.

Meanwhile, the second form of Islamic religious education curriculum is the Islamic religious education curriculum under the National Education Service's auspices. In this curriculum, all separate Islamic subjects are put together in one special subject with a particular hour, namely the Islamic Religious Education subject. This subject is usually taught in schools under the auspices of the education office, namely subjects. However, several schools try to combine the two curricula into a typical school curriculum building in its application. The benefits of implementing the Islamic religious education curriculum for students in an educational institution can be seen from the impact of worship and the impact of changes in students' character (Wibowo, 2010).

Before discussing the structure of the curriculum for Islamic education in elementary schools, it is necessary for the authors to first describe the structure of the curriculum for SD / MI globally. In the Ministry of Education, Regulation No.
57 of 2014 has been decided. The position of Islamic education is included in the subject category of group A, with several core objectives as described above. On this basis, the ministry of education implemented a change in the Islamic religious education curriculum structure. The structure of the curriculum for Islamic religious education in Indonesia has gone through several changes, among which the most fundamental changes are regarding the number of hours of Islamic education in one week. In the KTSP curriculum (Education Unit level curriculum), Islamic education in SD (elementary schools) only gets a portion of 2 hours of lessons per week, but after passing several studies and because of the many criticisms from various parties regarding the small number of hours of Islamic education lessons, Finally, in the new curriculum, namely the 2013 curriculum, the number of hours of lessons for Islamic education in SD (elementary schools) at each grade level is added to 4 lesson hours (Pendidikan, 2019).

From the building of the Islamic religious education curriculum, which is quite strong as the description above, it turns out that many are considered to be less than optimal in its implementation. Many factors can influence the imbalance in the implementation of the Islamic religious education curriculum. These factors can at least be divided into two broad outlines, namely, external and internal factors. External factors include lack of public awareness, including parents and guardians of the importance of Islamic religious education, environmental conditions around the school that are not supportive of providing good models, advances in modern science and technology that have eroded students' religious character widened traditional values and values modernity. While the second factor is internal factors which 
include: lack of teacher competence as the primary source of student learning, the relationship between religious teachers and students which is limited to formality within the scope of teaching in schools alone, and does not continue outside of school, which is still oriented towards knowledge only and has not touched much on the applicable realm (Rouf, 2015). The above problems, it can be understood that the right solution needs to be continually sought so that Islamic religious education can significantly impact the development of quality human resources in Indonesia.

\section{Management of Integrated Madrasah Diniyah Curriculum Development}

In this article, it is necessary first to understand the main topic study locations' profile that SD Khazanah Ilmu is a fundamental education institution that has implemented several curricula in its teaching and learning process. At the beginning of the school's establishment, SD Khazanah Ilmu implemented the KTSP curriculum and the typical Khazanah Ilmu SD curriculum. Over time, the curriculum in SD Khazanah Ilmu also changed. It is initially implementing the KTSP curriculum (Education Unit Level Curriculum. However, gradually starting to apply the 2013 curriculum according to the ministry of education regulations, its implementation is adjusted to the regulations of the Sidoarjo education office, and the implementation of the 2013 curriculum is still ongoing today.

SD Khazanah Ilmu is a private Islamic education institution that was founded in 2010. The institution was founded by two brothers who are very experienced in education, namely Prof. Dr. Imam Bawani, MA. Furthermore, his younger sister named Mrs. Dr. Istikomah, M.Ag. According to the information, the first batch of SD Khazanah Ilmu only numbered 19 students, but it continues to increase in its development. The total number of students this year has reached 546 students. SD Khazanah Ilmu is a full day Islamic school that is not oriented towards any particular organization. The regular school said that our school is not a Muhammadiyah school nor an NU school, but our school is MUHAMMADINU (Muhammadiyah and NU). From the above statement, we can already see that this school was established to provide services in educational facilities that can be accessed by the wider community regardless of their organizational background.

For the curriculum at SD Khazanah Ilmu, there are three curricula: the compulsory national education curriculum, the Ministry of Religion curriculum, and the typical school curriculum. In this school, there is a uniqueness that will not be found in any educational institution in Sidoarjo, namely the Madrasah Diniyyah program, which is integrated with private non-pesantren Islamic elementary schools. The Madrasah Diniyyah in question still adheres to the Madrasah Diniyyah curriculum that has been established by the Ministry of Religion. Nevertheless, slight modifications to the packaging of the material should use classical Arabic books. In this school, these materials are summarized by being given modifications or adding exciting items in the form of pictures or other items packaged in a textbook that will be printed and distributed to each student at each grade level. In this school, all students registered as elementary school students will automatically be registered as Madrasah Diniyyah students. Later on, when they graduate, they will also get two certificates at once, namely, an elementary school certificate validated by the head of the Sidoarjo education office and a Madrasah 
diniyah certificate legalized by the head of the PD Pontren Section of the Ministry of Religion Sidoarjo.

Some of the excellent programs at SD Khazanah Ilmu that aim to improve the quality of education in this school are, 1) The language familiarization program "English and Arabic" this habituation program is supported by the preparation of pocketbooks in English and Arabic, which students will study every day. Before starting learning, accompanied by their respective homeroom teachers. Besides, schools also always bring foreign teachers from various countries to strengthen aspects of the two languages. They were deliberately brought in to provide language deepening to teachers and students intensively for six months each academic year. 2) The memorization program of the Qur'an, Hadith, and Prayers, this program is also supported by the recruitment of highly qualified assistant teachers in this field accompanied by the publication of pocketbooks for memorizing the Qur'an, Hadith, and Prayers. Prayer that every year, there will be perfection. 3) Implementation of the BTQ (Read and Write Al-Quran) program. This program has been structured systematically. It can be implemented every day, and evaluation is held every semester with teaching teachers who have tested the al-Qur'an reading. 4) Self Development Program (PD).

This program is intended to map and group students to explore and increase each student's interest and talent. This program is also supported by a competition preparation coaching program with particular supervisors in each field. It also prepared rewards for students and teachers who have successfully made achievements at each competition event from the village level to the national level with different nominal amounts. 5) Outbound and Outdoor
Learning Program, this program is held annually by visiting educational places in the open as a means of recreation and education for students. 6) Professional development program and work evaluation of educators and education personnel. This program is carried out precisely every Saturday from 07.30 to 11.00, which includes all kinds of activities aimed at increasing the ability of teachers and educational personnel and work evaluation for the week that is carried out by the principal.

7) Character habituation program, this program is aimed at teachers and students with a program arrangement that has been compiled and agreed upon to be implemented in teaching and learning activities at school and daily activities at home. 8) The program of cooperation with parents, the form of cooperation here includes supervision of children and also supervision of schools via a Web page and a unique number that can be accessed by each student's guardian and later there will be an admin officer who will read and provide responses after a group discussion at school.

In addition to implementing the 2013 curriculum and the typical school curriculum, SD Khazanah Ilmu also imposed a curriculum from the Ministry of Religion, which was realized by the Madrasah Diniyah program, which was integrated into schools, this integrated Madrasah Diniyah program has existed since the second or third year after the establishment of the school.

Implementing the integrated Madrsasah Diniyyah program has gone through a relatively long process, especially in curriculum development. In curriculum development, SD Khazanah Ilmu has gone through stages that are a function of management. These stages include planning, organizing, actuating, controlling, and evaluating. The description of the curriculum 
development process at SD Khazanah Ilmu at each stage is as follows: First, Planning (planning), which is the planning process for the development of the integrated Madrasah Diniyah curriculum at SD Khazanah Ilmu was first initiated by the school founder, Mr. Imam Bawani as the head of the Institute Khazanah Ilmu and also Mrs. Istikomah as the head of the education division of the Khazanah Ilmu Institute, who at the beginning of the school's establishment she served as the head of SD Khazanah Ilmu.

The discourse on developing the reintegration Madrasah Diniyah curriculum concept arose from the aspirations of the founder who wanted to establish a public education institution that was thick with Islamic breaths, especially in the field of moral development and Arabic language development. At the same time, Imam Bawani, as the head of the institution, was still active in the Regional Office of the Ministry of Religion of East Java, so he began to study the possible concepts for him to apply in the institution he was going to establish, taking into account the idea of integrating the ministry of education and the ministry of religion. Besides, Mrs. Istikomah also conducted a comparative study to several schools with a superior predicate to find materials for the formulation of the Madrasah Diniyah curriculum design to be developed, while the initial goal of developing the integrated Madrasah Diniyah curriculum was as a supplement to Islamic Religious Education at SD Khazanah Ilmu.

The next process in developing the integrated Madrasah Diniyah curriculum is to hold a special joint meeting to discuss curriculum development between school principals, madrasah principals, teaching teachers, and school committees by inviting Prof. Imam Bawani and also Mrs. Istikomah as a team of experts in the field of Islamic education. From the results of the meeting, it was finally decided to formulate Madrasah Diniyah school. Also, Madrasah Diniyah textbooks to be used with material from SD PAI books, MI books, and Madrasah Diniyah books, with the main emphasis on material Aqidah, morals and worship, the formulation of school hours, and textbooks for Madrasah Diniyah at SD Khazanah Ilmu were entrusted to the principal of Madrasah Diniyah at first. They then collaborated with the waka curriculum after the waka ranks were formed.

The integrated Madrasah Diniyah curriculum development process will continue to be carried out every year, especially before starting the new school year. In planning curriculum development, SD Khazanah Ilmu has met the requirements for mandatory foundations in curriculum development. While the basics of curriculum development at SD Khazanah Ilmu are as follows: 1) Philosophical Foundation, Planning for integrated Madrasah Diniyah curriculum development in SD Khazanah Ilmu is based on the main goal is to supplement the Islamic Religious Education in these schools. Besides, in designing the curriculum at SD Khazanah Ilmu SD, it is also by bringing in people who are experts in Islamic matters from al-Azhar University in Egypt to assist in the design of Madrasah Diniyah textbook materials so that the contents are suitable and not against Islamic law. 2) Psychological basis, planning for integrated Madrasah Diniyah curriculum development in SD Khazanah Ilmu has been adapted to students' conditions starting from lesson hours to teaching materials and teaching methods aimed at children at the elementary level. According to the age level and class of students. Besides, the formulation of the Khazanah Ilmu SD curriculum draft is also based on the statement that education in elementary schools must have a more 
integrated and thematic-based curriculum development.

The approach used in the planning process for the integrated Madrasah Diniyah curriculum development at SD Khazanah Ilmu is a combination of the Top-Down approach and the Grass Roots approach, were in the process, the initial ideas and concepts of curriculum development come from the founders who are then explained through the principal to then forwarded to the person in charge of each field. The principal appoints Madrasah Diniyah to draft the Madrasah Diniyah curriculum development concept, then the head of Madrasah Diniyah discusses with the teachers before deciding which form of Madrasah Diniyah development will be applied. The approach is a person's point of view towards a specific process. The point of view here is general so that the curriculum development approach can be interpreted as a perspective on the implementation process in curriculum development management. According to Hanun Asrohah, two approaches are commonly applied in the curriculum development process: the top-down approach and the grassroots approach (Asrohah and Alamsyah, 2013).

Second, organizing, which is organizing curriculum development at SD Khazanah Ilmu implemented by appointing several people who are given special responsibility in the curriculum development team, including holding a special curriculum development meeting where discussions are opened to provide input from the design design. Curriculum to be passed. The person in charge is assigned to make preparations for implementing the curriculum by designing the framework for teaching hours and teaching materials, distributing teachers, and designing the evaluation form. The parties who are given responsibility for, of course, curriculum assists the school leadership as the designer of the curriculum framework, the principal of Madrasah Diniyah as the coordinator and designer of teaching materials and forming a teaching team including determining special teachers to teach Madrasah Diniyah classes, as well as PAI teachers, as providers input regarding the materials needed in the development of this curriculum. Third, Actuating (implementation), namely the implementation of a curriculum that has been designed and has been approved by the head of the Sidoarjo education office with a different curriculum structure from other schools. The teaching and learning process of Madrasah Diniyah for all students of SD Khazanah Ilmu by allocating special learning hours in the afternoon after the learning hours at SD are over. They were forming a teaching team for Madrasah Diniyah, which is different from the teaching team at SD, using outstanding Madrasah Diniyah textbooks that have been compiled by the curriculum development team as the primary teaching material.

For more details regarding the implementation of integrated Madrasah Diniyah curriculum development at SD Khazanah Ilmu, it can be described in detail: 1) The structure of the new curriculum, In implementing the integrated Madrasah Diniyah curriculum development at SD Khazanah Ilmu, it has finally produced a curriculum structure that is rich in content of Islamic Religious Education. It has fulfilled the demands of the original objective of holding an integrated Madrasah Diniyah program at SD Khazanah Ilmu. Researchers have made comparisons of the curriculum structure between MI, SD Umum, and SD Khazanh Ilmu, which includes subjects included in the PAI category and non PAI subjects, without including local content subjects extra-curricular programs. 
The comparison results are as follows: a) The structure of the MI curriculum using a sample of class VI. Following the Decree of the Minister of Religion No. 184 of 2019, the total number of lesson hours is 42 lesson hours, and the PAI lesson hours are 10 lesson hours, the rest are other general subjects totaling 32 lesson hours. The percentage of Islamic education lessons per week is 10 / 42x100 $=23.8 \%$. b) Elementary school curriculum structure using a sample class VI based on Permendikbud No. 57 of 2014 , a total of 36 teaching hours. Islamic Religious Education lesson hours 4 lesson hours. The rest is time for other general lessons totaling 32 lesson hours. Percentage of Islamic Education hours per week: $4 / 36 \times 100=11.1 \%$. c) The curriculum structure of SD Khazanah Ilmu using a sample of class VI based on the 2020 Khazanah Ilmu SD curriculum document, the total number of lesson hours is 44 lesson hours. Islamic Religious Education lesson hours 4 lesson hours + Madrasah Diniyah lesson hours 8 lesson hours. Total of 12 hours of lessons. The rest are other general subjects totaling 32 lesson hours. Percentage of weekly PAI lesson hours: $12 / 44 \times 100=27.3 \%$.

2) Arrangement of special Madrasah Diniyah lesson hours, a concrete form of implementing the integrated Madrasah Diniyah curriculum development in SD Khazanah Ilmu is by designing special Madrasah Diniyah subject hours. As with the data exposure in the previous discussion that has shown a particular Madrasah Diniyah lesson schedule for students from grades I to VI, Madrasah Diniyah's study hours for classes I-II are held at 14:15-14.50 according to the specified schedule. Meanwhile, learning hours for classes IIIVI are held starting at 14:15-15.25 with subjects according to the subject that is informed; 3) Forming a special Madrasah
Diniyah teaching team In order to create a quality Madrasah Diniyah at SD Khazanah Ilmu, a special team was formed to teach in the Madrasah Diniyah class. The teaching team of Madrasah Diniyah consists of teachers who are competent in religious scholarship. Some of the Madrasah Diniyah teaching teams are homeroom teachers in elementary school classes who have more abilities in Islam's scientific field.

The rest are special teachers recruited to teach special classes at Madrasah Diniyah. 4) Preparation of outstanding Madrasah Diniyah textbooks. In preparing the textbooks used in the Madrasah Diniyah class, the drafting team has formulated specific materials that will be included in the textbook. The materials covered in this Madrasah Diniyah textbook are taken from MI books, Madrasah Diniyah books, and PAI books with a continuous development process. This textbook, which is specially designed for the Madrasah Diniyah class, consists of six volumes, namely volume 1 to volume 6 , where you will get textbooks that are different from other class levels at each grade level. Textbook volume 1 for grade I students, textbook volume 2 for grade II students, textbook volume 3 for grade III students, textbook volume 4 for grade IV students, textbook volume 5 for grade $\mathrm{V}$ students, textbook volume 6 for grade VI students. The materials in this particular Madrasah Diniyah textbook include the necessary materials of the Islamic Religion, namely, Aqidah, Worship, and Morals / muamalah. These materials are summarized in a special Madrasah Diniyah course package, including Arabic, SKI (Islamic Cultural History), Mapel AlQur'an Hadith, Mapel, Aqidah Akhlak, and Mapel Fiqih.

The fourth is Controlling (supervision). Supervising curriculum development at SD Khazanah Ilmu is carried out every day when learning hours 
take place in each class. This supervision is carried out by the head of the education division, the principal, and Madrasah Diniyah. This supervisory program's scheduling is carried out flexibly and is not bound by a unique schedule. Fifth, Evaluating. Evaluating the implementation of curriculum development at SD Khazanah Ilmu is carried out every week on Saturdays by gathering teachers every week on that day to discuss the learning process for one week. Evaluation is carried out by examining learning problems in the classroom, including the teacher's ability to deliver lessons in which the evaluation of material books has been taught for one week. Apart from evaluations every week, there is also a semester evaluation. This evaluation form is to conduct end-ofsemester assessments for students and distribute semester report cards for teachers and students.

Besides, evaluations are also carried out annually by forming a special team to assess deficiencies in the learning process for one year. The evaluation carried out is related to the evaluation of teachers, evaluation of teaching materials, and evaluation of students' learning outcomes. The evaluation of the implementation of curriculum development at SD Khazanah Ilmu was carried out by the head of the education division, the principal of SD Khazanah Ilmu, Madrasah Diniyah, and also the Madrasah Diniyah teaching teacher. So, SD Khazanah Ilmu has carried out a series of management processes and functions in developing its curriculum. Management processes and functions that have been applied in curriculum development at SD Khazanah Ilmu include planning, organizing, implementing, controlling, and evaluating.

\section{CONCLUSION}

Based on the discussion carried out through the process of searching for data, data exposure, data reduction, and data analysis according to the focus of the research problem, then in this final section, the researcher concludes that the implementation of integrated management of Madrasah Diniyah curriculum development at SD Khazanah Ilmu is carried out with several stages including one the founders of the institution initiate) Planning, the curriculum development planning process.

By conducting an assessment of the applied concepts by approaching the ministry of religion and the education office. Besides, a comparative study of several leading institutions before holding a workshop with a team of experts to formulate a new curriculum framework and form a curriculum development team and their duties. In planning curriculum development based on the foundation, philosophical, psychological, sociological, and juridical using a combination approach between Top-Down and Grass Roots; 2) Organizing.

The process of organizing curriculum development is carried out by appointing a person in charge of the curriculum development team to carry out specific tasks. The people who are given this responsibility include the principal, curriculum assistant, head of Madrasah Diniyah, and PAI teachers. 3) Implementation, the form of implementing this curriculum development includes designing a new curriculum structure that is different from other institutions, with an emphasis on adding PAI hours. The special Madrasah Diniyah school hours to form a special Madrasah Diniyah teaching team, and the preparation of particular Madrasah Diniyah textbooks. 
4) Supervision, the process of monitoring curriculum development is carried out every day during the teaching and learning process and is carried out by the head of the education division, the principal, and Madrasah Diniyah. 5) Evaluation: This form of curriculum development evaluation includes a shortterm evaluation conducted every week on Saturdays. The medium-term evaluation conducted at the end of each semester. Moreover, long-term evaluation is conducted at the end of each academic year. Evaluations carried out are related to teacher evaluation, evaluation of teaching materials, and student learning outcomes. The evaluation of the implementation of curriculum development at SD Khazanah Ilmu was carried out by the head of the education division, the principal of SD Khazanah Ilmu, Madrasah Diniyah, and also the Madrasah Diniyah teaching teacher. In essence, all education management in this madrasah is integrated systemically.

\section{REFERENCES}

Al-Jazairi, A. B. J. (2009). Minhajul Muslim. Al-Madinah Al-Munawwaroh: Maktabah Ulum Wal Hikmah.

Burhan Al-Islam Al-Zarnuji. (2004). Ta'lim Al-Muta'alim Thariq Al-Ta'allum. Sudan: Daaru Al-Suudaniyyah Li AlKutub.

Djahid, M. (2016). Penyelenggaraan Pendidikan Madrasah Diniyah Takmiliyah Di Ponorogo. Muaddib: Studi Kependidikan Dan Keislaman, 6(1), 21. https://doi.org/10.24269/muaddib .v6n1.2016.21-41

Hamalik, O. (2007). Manajemen Pengembangan Kurikulum. Bandung: Remaja Posdakaraya.

Hanun Asrohah dan Anas Amin Alamsyah. (2013). Pengembangan
Kurikulum. Surabaya: Kopertais IV Press.

Hidayat, M. C., \& Mahfud, C. (2019). Potential Development Management of Students in Islam. Ta'dib: Journal of Islamic Education Jurnal Pendidikan Islam), 24(2), 293-302.

Hidajati, F., Wulandari, D., Kholiq, A., \& Mahfud, C. (2019). Madrasah Dan Sejarah Sosial Pendidikan Islam. Nur El-Islam: Jurnal Pendidikan Dan Sosial Keagamaan, 6(1), 1-14.

Ibrahim, M. (2016). Naskah Akademik Pengembangan Kurikulum. Surabaya: Kementerian Riset Teknologi dan Pedidikan Tinggi Universitas Negeri Surabaya.

Indonesia, N. R. (2003). Undang-Undang Dasar 1945 No.20 Tentang Sistem Pendidikan Nasional. Indonesia.

Indonesia, P. R. Permendikbud Nomor 57 Tahun 2014. , Kemendikbud (2014).

Ismail, I. (2018). Madrasah Diniyah Dalam Multi Perspektif. KABILAH: Journal of Social Community, 2(2), 254 282.

https://doi.org/10.35127/kbl.v2i2. 3137

Jalaluddin. (2012). Psikologi Agama. Jakarta: Raja Grafindo Persada.

Kementerian Agama, S. (2017). Standart Kurikulum Madrasab Diniyah Dan Petunjuk Teknis Penyelenggaraan Ujian Semester Bersama, Sidoarjo: Islamadina.

Kisbiyanto. (2014). Organizational Behavior Model At Madrasah Diniyah in Kudus, Indonesia. Qudus International Journal of Islamic Studies, 1(2), 221-244. https://doi.org/10.21043/QIJIS.V 1I2.184

Krisdiyanto, Gatot, Muflikha, Sahara, Mahfud, Choirul. (2019). Sistem Pendidikan Pesantren dan 
Tantangan Modernitas. Tarbawi: Jurnal Ilmu Pendidikan 15 (1), 11-21.

Mahfud, C. (2019). Developing Islamic Material Based on Spirit of National Tolerance. Jurnal

Pendidikan Glasser, 3 (1), 70-77.

Mahfud, Choirul. (2020). Understanding Political Reform and Islamic Education Position in Indonesia. AL-MURABBI: Jurnal Studi Kependidikan dan Keislaman 6 (2), 130 136.

Mahfud, Choirul. (2019). The Paradox of Islamic Education in Indonesia, Ta'dib: Jurnal Pendidikan Islam 8 (2), 618-625.

Mahfud, Choirul. (2016). Politik Pendidikan Islam. Yogyakarta: Pustaka Pelajar.

Mahfud, C. (2018). Chinese Muslim Community Development in Contemporary Indonesia: Experiences of PITI in East Java. Studia Islamika, 25(3), 471-502.

Mahfud, C., Prasetyawati, N., Wahyuddin, W., Muhibbin, Z., Agustin, D. S. Y., \& Sukmawati, H. (2018). Religious Radicalism, Global Terrorism and Islamic Challenges in Contemporary Indonesia. Jurnal Sosial Humaniora (JSH), 11(1), 8-18.

Mahfud, C. (2019). Evaluation of Islamic Education Curriculum Policy in Indonesia. Premiere Educandum: Jurnal Pendidikan Dasar dan Pembelajaran, 9(1), 34-43.

Mahfud, C. (2019). The Genealogy Of Social History Of Islamic Education Politics In Indonesia. Al-Tadzkiyyah: Jurnal Pendidikan Islam, 10(1), 1-12.

Minarti, S. (2013). Ilmu Pendidikan Islam: Fakta Teoritis-Filosofis dan AplikatifNormatif. Jakarta: Amzah.

Mundiri, A., \& Hasanah, R. U. (2018). Inovasi Pengembangan Kurikulum Pai Di Smp Nurul Jadid. Tadrib: Jumal Pendidikan Agama Islam, 4(1), 40-68. https://doi.org/10.19109/tadrib.v4 i1.1721

Mustari. (2013). Manajemen dalam pendidikan Dalam Konteks Indonesia. Bandung: Arsad Press.

Mu'ammar, M. A., \& Mahfud, C. (2020). The Democratic Education of Ivan Illich: Critical Comments from an Islamic Perspective. Journal of Critical Reviews, 7(8), 2706-2715.

Muyasaroh dkk. (2020). The Utilization of Gadget in Maintaining Prophetical Values in the Millennial Generation. International Journal of Psychosocial Rehabilitation 24 (4), 5602-5615.

Nizah, N. (2016). Dinamika Madrasah Diniyah: Suatu Tinjauan Historis. Edukasia: Jurnal Penelitian Pendidikan Islam, 11(1), 181-202. https://doi.org/10.21043/edukasia .v11i1.810.

Nuroni, E., \& Khambali, K. (2016). Implementasi Pembentukan Karakter Khas Madrasah Pada Peserta Didik Di MI Asih Putera Kota Cimahi. Ta'dib: Jurnal Pendidikan Islam, 5(1), 61-70.

Nurzaman. (2018). The development of madrasah diniyah in Indonesia. International Journal of Religious Studies, 6(2), 81-104.

Pendidikan, K. Peraturan Menteri Pendidikan Dan Kebudayaan Republik Indonesia Nomor 57 Tabun 2014 Tentang Kurikulum $2013 \quad$ Sekolah Dasar/Madrasah Ibtidaiyah., (2019).

Puara, M. P. (2018). Manajemen Pengembangan Kurikulum Terintegrasi Di SDIT Nurbidayah Surakarta Tabun Pelajaran 2017/ 2018. Institut Agama Islam Negeri Surakarta.

Rahmawati, R., Yahiji, K., Mahfud, C., Alfin, J., \& Koiri, M. (2018). Chinese ways of being good Muslim: from the Cheng Hoo Mosque to Islamic education and media literacy. Indonesian Journal 
of Islam and Muslim Societies, 8(2), 225-252.

Rouf, A. (2015). Potret Pendidikan Agama

Islam Di Sekolah Umum. Jurnal Pendidikan Agama Islam UIN Sunan Ampel, 03(No. 1 (2015)), 187-206. https://doi.org/DOI:

http://dx.doi.org/10.15642/jpai.20 15.3.1.187-206

Subakti, G. E. (2012). Implementasi pendidikan agama Islam di SD Islam Terpadu (Studi deskriptif pada SD Plus Islam TerpaduBhaskara SukamelagSubang). Jurnal Tarbawi, 1(1), 21-32.

Syaifuddin, M. A., Anggraeni, H., Khotimah, P. C., \& Mahfud, C. (2019). Sejarah Sosial Pendidikan Islam Modern Di Muhammadiyah. TADARUS, 8(1).

Wibowo, A. (2010). Dampak Implementasi Kurikulum PAI Terhadap Perilaku Keagamaan. Analisa, 17(1), 117. https://doi.org/10.18784/analisa.v 17 i1.118. 